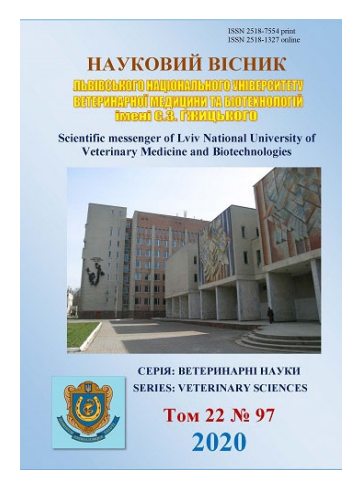

\section{Науковий вісник Дьвівського національного університету ветеринарної медицини та біотехнологій імені С.3. Гжицького. Серія: Ветеринарні науки}

\author{
Scientific Messenger of Lviv National University \\ of Veterinary Medicine and Biotechnologies. \\ Series: Veterinary sciences
}

doi: 10.32718/nvlvet9715

https://nvlvet.com.ua/index.php/journal

UDC 619:615(075.8):616.311:612.591.43+613.71:577.1

\title{
The role of gas mediators of nitrogen (II) oxide and hydrogen sulfide in the development of pathochemical changes in the mucous membrane of rats at water-immobilization and adrenaline-induced stress modeling
}

\author{
N. Motko ${ }^{1}$, I. Fomenko ${ }^{2}$, O. Vozna ${ }^{1}$ \\ ${ }^{1}$ Stepan Gzhytskyi National University of Veterinary Medicine and Biotechnologies Lviv, Ukraine \\ ${ }^{2}$ Danylo Halytsky Lviv National Medical University, Lviv, Ukraine
}

Article info

Received 05.02.2020

Received in revised form 05.03 .2020

Accepted 06.03.2020

Stepan Gzhytskyi National University of Veterinary Medicine and Biotechnologies Lviv, Pekarskaya Str., 50, Lviv, 79010, Ukraine. Tel.: +38-097-933-96-40 E-mail:biochem@lvet.edu.ua

Danylo Halytsky Lviv National Medical University Pekarska str., 69, Lviv, 79010, Ukraine.
Motko, N., Fomenko, I., \& Vozna, O. (2020). The role of gas mediators of nitrogen (II) oxide and hydrogen sulfide in the development of pathochemical changes in the mucous membrane of rats at water-immobilization and adrenaline-induced stress modeling. Scientific Messenger of Lviv National University of Veterinary Medicine and Biotechnologies. Series: Veterinary sciences, 22(97), 88-94. doi: $10.32718 /$ nvlvet9715

Acute and prolonged psycho-emotional overstrain, i.e. stress, are the most frequent factors of ulcer formation in the digestive system. Therefore, the study of molecular mechanisms of stress impact is one of the most promising directions of modern experimental gastroenterology. However, the features of its molecular-biochemical action on the metabolic processes in the digestive system remain insufficiently studied. In this regard, we performed a comparative analysis of changes in indicators of systems of gas mediators of nitrogen (II) oxide and hydrogen sulfide synthesis at water-immobilization and adrenalineinduced stress modeling in experiments on white non-linear rats. Water-immobilization stress (WIS) was modelled by immobilizing animals in a plastic container, and adrenaline-induced stress (AIS) was modelled by injecting adrenaline at a dose of $2 \mathrm{mg} / \mathrm{kg}$ intraperitoneally. Modelling WIS caused formation of erosion and spot hemorrhage, located mainly along the folds of the fundus of the stomach. In this case, more noticeable changes were observed in the 5-hour WSI model. Injecting adrenaline at AIS model caused development of structural-hemorrhagic damage in the pyloric part and body of the stomach. The biochemical response to stress is complex, and the release of catecholamines is not the only case of stress. The synthesis of hormones such as glucagon, somatotropin and renin is activated. However, the most important role is played by cortisol, which level of growth in blood is measured to assess the degree of stress development. In our studies, changes in cortisol level in blood under different types of stress modeling (WIS and AIS) had their own peculiarities: at WIS conditions cortisol concentration increased sharply and remained high for 5 hours, while adrenaline did not cause the growth of this "stress hormone". In our studies, in both models of stress-induced ulcerogenesis there were significant changes to the content of $\mathrm{H}_{2} \mathrm{~S}$ and NO, that confirms the significant role of these substances in development and progression of ulcerogenesis in the digestive system. Thus, $\mathrm{H}_{2} \mathrm{~S}$ concentration decreased at WIS and AIS. There is a significant increase in nitrogen oxide production in both WIS with different duration of action and AIS, which is caused by multiple activation of the inducible isoform of NO-synthase. Therefore, in experimental stress-induced ulcerogenesis, the metabolism of L-arginine in the mucous membrane of stomach is equally shifted towards the formation of NO, that under conditions of strengthening of free radical processes serves as a prerequisite for activation of oxidative-nitric processes and leads to the formation of structuralhemorrhagic damage to the surface of the mucous membrane of stomach. Our studies also show that ulcerative damage to the mucous membrane of stomach in all the types of studied stress was accompanied by an increase in myeloperoxidase activity, indicating an increase in permeability of hemocapillaries due to the development of the inflammatory process.

Key words: water-immobilization stress, adrenaline-induced stress, gastric mucosa, nitrogen (II) oxide, hydrogen sulfide. 


\title{
Роль газових медіаторів нітроген (II) оксиду та гідроген сульфіду в розвитку патохімічних змін у слизовій оболонці щурів при моделюванні водно-імобілізаційного та адреналін-індукованого стресу
}

\author{
Н. Р. Мотько ${ }^{1}$, І. С. Фоменко ${ }^{2}$, О. Є. Возна ${ }^{1}$ \\ IЛьвівський національний університет ветеринарної медицини та біотехнологій імені С. З. Гжицького, \\ м. Львів, Україна \\ ${ }^{2}$ Львівський національний медичний університет імені Данила Галиџького, м. Львів, Украйна
}

\begin{abstract}
Найчастіше чинниками виразкоутворення в травній системі служать гострі та тривалі психоемоційні перенапруження, тобто стрес. Тому дослідження молекулярних механізмів впливу стресу є одним із найперспективніших напрямків сучасної експериментальної гастроентерології. Проте особливості його молекулярно-біохімічної дії на обмінні проиеси у травній системі залишаються недостатньо вивченими. В зв'язку з иим нами було проведено порівняльний аналіз змін показників систем синтезу газових медіаторів нітроген (II) оксиду та гідроген сульфіду за умов моделювання водно-імобілізаційного та адреналін-індукованого стресу в дослідах на білих нелінійних щурах. Водно-імобілізаційний стрес (ВIC) моделювали шляхом іммобілізації тварин у пластиковому контейнері, адреналін-індукований стрес (АIC) моделювали шляхом введення адреналіну в дозі 2 мг/кг внутрішньоочеревинно. Моделювання ВІС зумовлювало формування ерозій та точкових крововиливів, розташованих, головним чином, уздовж складок фундальної частини шилнка. При цьому більш виражені зміни спостерігали при моделі 5-годинного ВІС. Введення адреналіну в моделі АІС зумовлювало розвиток структурно-геморагічних ушкоджень у пілоричній частині та тілі шлунка. Біохімічна відповідь на стрес комплексна, а вивільнення катехоламінів не єдина подія при стресі. Активується синтез таких гормонів, як глюкагон, соматропін та ренін. Проте найвагомішу роль відіграє кортизол, за рівнем зростання в крові якого прийнято оцінювати ступінь розвитку стресу. В наших дослідженнях зміни рівня кортизолу в крові за умов моделювання різних видів стресу (BIC та АIC) мали свої особливості: за умов ВІС кончентрація кортизолу різко зростала і залишалась на високому рівні протягом 5 год. Водночас дія адреналіну не викликала зростання иього “стрес-гормону”. В наших дослідженнях при обидвох моделях стрес-індукованого ульиерогенезу мали місие суттєві зміни вмісту $\mathrm{H}_{2} \mathrm{~S}$ та $\mathrm{NO}$, що підтверджує значну роль иих речовин у розвитку та прогресії ульиерогенезу в органах травної системи. Так, концентрація $\mathrm{H}_{2} \mathrm{~S}$ знижувалась при ВIC та АIC. Як при ВІС різної тривалості діï, так $і$ при AIC відбувається значне зростання продукиії нітроген оксиду, зумовлене багаторазовою активачією індуцибельної ізоформи NOсинтази. Отже, при експериментальному стрес-індукованому ульцерогенезі метаболізм L-аргініну в СОШ однаковою мірою змішується в бік утворення $N O$, шо за умов посилення вільнорадикальних прочесів служить передумовою активаиії оксидативнонітративних процесів та призводить до утворення структурно-геморагічних ушкоджень поверхні слизової оболонки шлунка.
\end{abstract}

Ключові слова: водно-імобілізаиійний стрес, адреналін-індукований стрес, слизова оболонка илунка, нітроген оксид, гідроген сульфід.

\section{Вступ}

Одним із найпотужніших чинників розвитку деструктивних ушкоджень в слизовій оболонці шлунка (СОШ) є стрес (Alhazzani et al., 2012; Fomenko et al., 2014; Brzozowski et al., 2017). Його ульцерогенний вплив має комплексний характер і здійснюється на різних рівнях: від центральних відділів ЦНС та системи гіпоталамус-гіпофіз-кора надниркових залоз до клітинного та молекулярного рівнів (Mönnikes et al., 2001; Alhazzani et al., 2012; De Palma et al., 2014). Дія стресу викликає активацію нейронів паравентрикулярного ядра гіпоталамуса, що впливає на продукцію слизу, об'єм шлункового соку, його кислотність, моторику шлунка та кишки (Filaretova et al., 2012; Huerta-Franco et al., 2013). Молекулярні ефекти у СОШ зумовлені, головним чином, зростанням продукції так званих “стресгормонів": катехоламінів та глюкокортикоїдів. Катехоламіни (адреналін, норадреналін), вивільняючись у кров, чинять вазоконстрикторну дію, зумовлюючи порушення кровоплину, ішемію слизової оболонки гастродуоденальної зони та, як наслідок, різке зростання інтенсивності оксидативних процесів (Kudryavtsev et al., 2014; Fomenko, 2015). Таким чином, одним 3 основних механізмів ульцерогенної дії стресу $€$ вазоконстрикція кровоносних судин внаслідок дії катехоламінів, зокрема адреналіну, що і служить причиною розвитку ендотеліальної дисфункції, яка характеризується збільшенням зростанням інтенсивності процесів вільнорадикального окиснення (Fomenko, 2015). Паралельно відбувається зростання інфільтрації СОШ лімфоцитами, які своєю чергою активують вивільнення кисневих радикалів та зумовлюють формування запального процесу. Роль газових медіаторів - нітрогену оксиду (NO) та гідрогену сульфіду $\left(\mathrm{H}_{2} \mathrm{~S}\right)$ у біохімічних механізмах формування виразкових змін СОШ залишається недостатньо дослідженою. Тому метою дослідження було провести порівняльний аналіз змін показників NO- та $\mathrm{H}_{2} \mathrm{~S}$-продукуючих систем за умов моделювання водно-імобілізаційного (BIC) та адреналініндукованого (АIC) стресу.

\section{Матеріал і методи досліджень}

Дослідження виконано на 32 білих нелінійних щуpax згідно 3 міжнародними умовами проведення експериментів $з$ лабораторними тваринами. Щурів утримували на стандартному раціоні віварію, для проведення досліду тварин брали натще, забезпечували безперешкодний доступ до води.

Тварин було розподілено на 4 групи: 1) інтактні; 2) ВIC, що моделювали шляхом іммобілізації тварин у пластиковому контейнері, після чого останній зану- 
рювали вертикально у воду $\left(23 \pm 0,5^{\circ} \mathrm{C}\right)$ до рівня мечоподібного відростка тварини упродовж трьох 3 половиною годин (Takagi et al., 1964); 3) ВIC аналогічний до умов у тварин групи 2 при подовженні часу експозиції до п'яти годин; 4) АIC, що моделювали шляхом введення адреналіну в дозі 2 мг/кг внутрішньоочеревинно натще (Belostockij, 1988). Забір матеріалу для досліджень проводили під тіопенталовим наркозом (40 мг/кг).

В гомогенатах СОШ вміст NO оцінювали за значенням концентрації суми нітрит-аніон + нітрат-аніон з використанням реактиву Гріса (Green \& David, 1982; Kiselyk et al., 2001). Активність NO-синтаз визначали за методом Раваєвої М. Ю. (Ravaieva, 2012), активність аргінази оцінювали за змінами концентрації сечовини (Geyer \& Dabich, 1971). Продукцію $\mathrm{H}_{2} \mathrm{~S}$ в гомогенатах СОШ оцінювали в реакції 3 N,Nдиметил-р-фенілендиаміном (Wilinski et al., 2011) в сироватці крові 3 р-фенілендиаміном. Активність мієлоперексидази визначали на основі реакції 3 одіанізидином (Bradley et al., 1982). Концентрацію кортизолу визначали 3 використанням стандартного набору “Кортизол-ІФА” та вимірювали величину оптичної густини на фотометрі "Stat-Fax" вертикального сканування при довжині хвилі 450 нм.

Результати оброблено 3 використанням пакету Statistika 7,0 ANOVA 3 апостеріорним попарним порівнянням груп.

\section{Результати та їх обговорення}

Моделювання ВIC супроводжувалось розвитком структурно-геморагічних уражень (СГУ) СОШ у вигляді ерозій та точкових крововиливів, розташованих, головним чином, вздовж складок фундальної частини шлунка, більш виражених при 5-годинній експозиції. Введення адреналіну зумовлювало розвиток СГУ СОШ у вигляді масивних та крапкових крововиливів, ерозій та виразок, локалізованих переважно у пілоричній частині та тілі шлунка (рис. 1). Заслуговує на увагу і той факт, що значна поверхня слизової оболонки за умов використання різних моделей стресу мала білесуватий колір, що свідчило про порушення кровоплину та розвиток гіпоксичного стану.

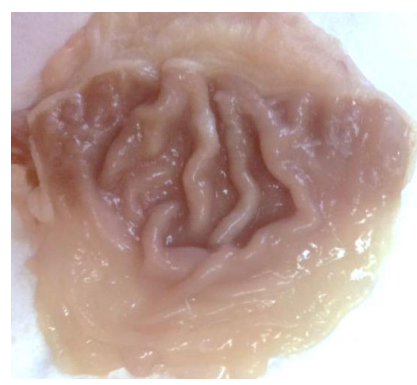

1

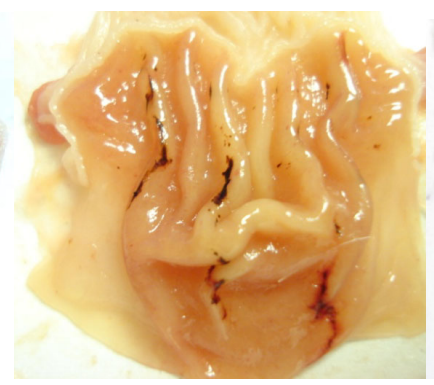

2

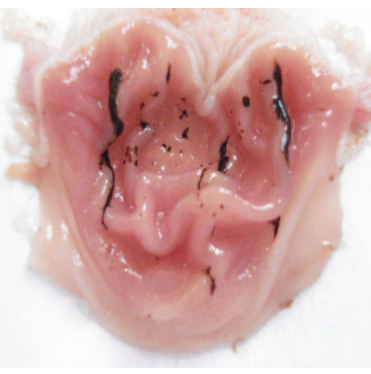

3

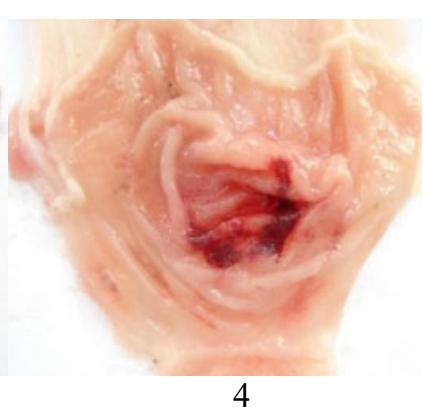

4

Рис. 1. Макроскопічний стан СОШ за умов норми та впливу ВIC різної тривалості та AIC. 1 - контрольна група тварин; 2 - ВІС упродовж 3,5 год; 3 - ВIC упродовж 5 год; 4 - AIC

Проведений гістологічний аналіз засвідчив, що розвиток деструктивних ушкоджень за умов моделювання ВIC характеризувався локальним руйнуванням слизового бар'єру, десквамацією поверхневого шару епітеліоцитів; формуванням ерозивно-виразкових ушкоджень, більш виражених за умов 5-годинної експозиції інфільтрацією зони ушкодження лейкоци- тами (рис. 2). Дія АIC зумовлювала розвиток гіпоксії внаслідок вазоконстрикції та призводила до руйнування епітеліального бар'єру СОШ, формування набряку, інфільтрації поліморфноядерними лейкоцитами та лімфоцитами слизової оболонки та до виникнення значно глибших, порівняно 3 впливом ВIC, деструктивних ушкоджень.

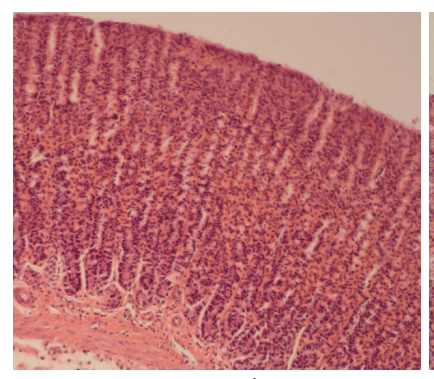

1

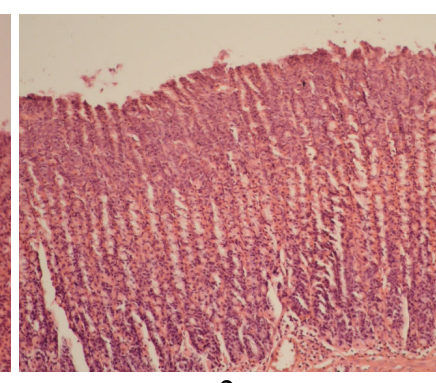

2

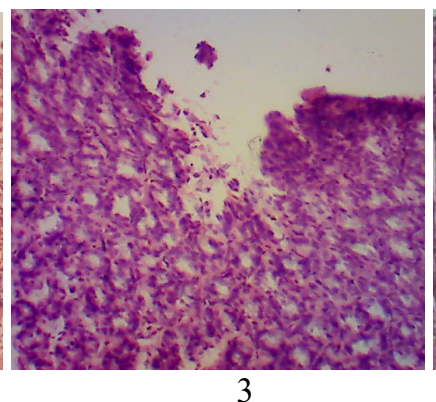

3

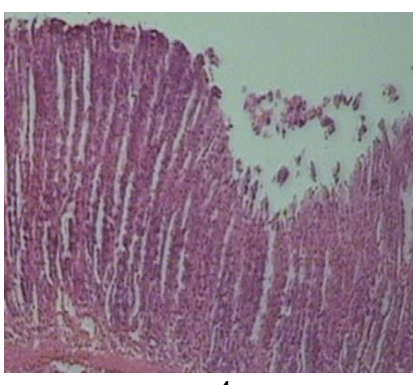

4

Рис. 2. Гістологічні зміни в СОШ за умов норми та при ВIC різної тривалості та $\mathrm{AIC}(\times 300)$. 1 - Контрольна група тварин; 2 - дія ВIC упродовж 3,5 год; 3 - вплив ВIС упродовж 5 год; 4 - дія AIC

Враховуючи те, що стрес характеризується активацією симпато-адреналової системи 3 подальшим виділенням не лише адреналіну, а й кортизолу (Filaretova et al., 2012), моделювання стресу в наших 
дослідженнях контролювали шляхом вимірювання рівня цього “стрес-гормону” в плазмі крові. За умов норми концентрація останнього становила $60,8 \pm 1,3$ нмоль/л, тимчасом як при 3,5-годинному стресі вона зростала на 48 \% (P $\leq 0,01)$, залишаючись приблизно на одному рівні й за умов дії ВIC тривалістю 5 годин. АІС практично не змінював концентрацію кортизолу (рис. 3 - А). Розвиток виразкових ушкоджень при усіх досліджуваних видах стресу супроводжувався зростанням активності мієлопероксидази
(МПО) (рис. 3 - В), що засвідчує інфільтрацію нейтрофілами. У тварин контрольної групи рівень активності цього ферменту був відносно низьким, тимчасом як розвиток виразкових ушкоджень при ВIC тривалістю 3,5 години підвищував активність майже удвічі (P $\leq 0,01)$. Подовження часу експозиції $\mathrm{BIC} \mathrm{до}$ 5 годин призводило до подальшого зростання активності мієлопероксидази. АІС зумовлював підвищення останньої майже утричі $(\mathrm{P} \leq 0,01)$.

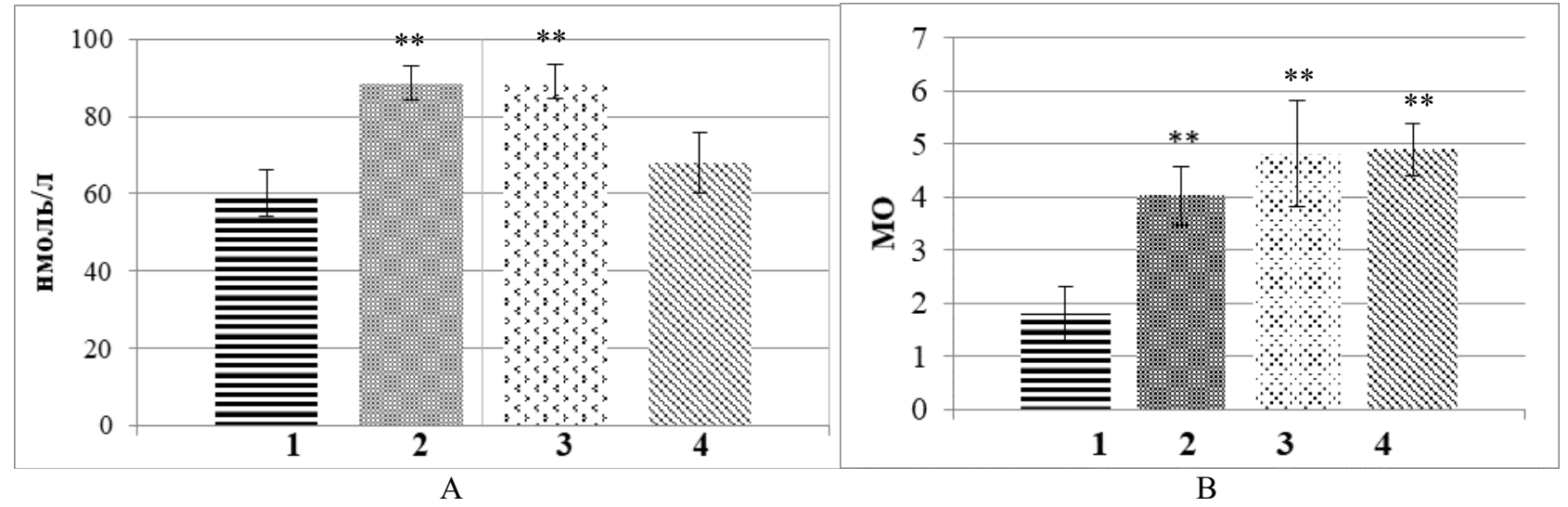

Рис. 3. Концентрація кортизолу в сироватці крові (А) та активність мієлопероксидази в гомогенатах СОШ (В) за умов норми та при АIC і ВIC різної тривалості $(\mathrm{M} \pm \mathrm{m}, \mathrm{n}=8) .1$ - контрольна група тварин;

2 - дія ВIC упродовж 3,5 год; 3 - вплив ВIC упродовж 5 год; 4 - дія АIC. ** - P $\leq 0,01$ порівняно 3 показниками тварин контрольної групи

Розвиток стрес-індукованого ульцерогенезу (СГУ) внаслідок моделювання стресу супроводжувався суттєвими змінами вмісту газових медіаторів $\mathrm{H}_{2} \mathrm{~S}$ та $\mathrm{NO}$, що підтверджує їх значну роль у розвитку та прогресії ульцерогенезу в органах травної системи. В наших дослідженнях за умов дії ВIC концентрація $\mathrm{H}_{2} \mathrm{~S}$ знижувалась як в СОШ, так і в сироватці крові. Зокрема, при ВIC упродовж 3,5 год концентрація $\mathrm{H}_{2} \mathrm{~S}$ в СОШ зменшувалась майже на $14 \%$, в сироватці крові - на $11 \%$. ВІС тривалістю в 5 год призводив до зниження концентрації $\mathrm{H}_{2} \mathrm{~S}$ на $15 \%(\mathrm{P} \leq 0,05)$ в СОШ (рис. $4-$ А). АIC спричиняв ще суттєвіше (на $33 \%, \mathrm{P} \leq 0,01$ ) падіння рівня $\mathrm{H}_{2} \mathrm{~S}$ в СОШ, тимчасом як в сироватці крові його концентрація була на рівні показників концентрації при ВIC.

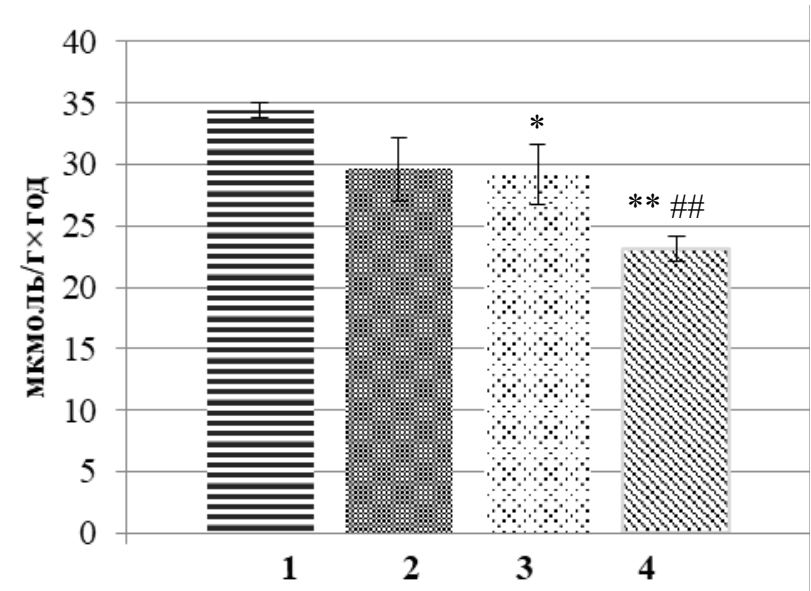

A

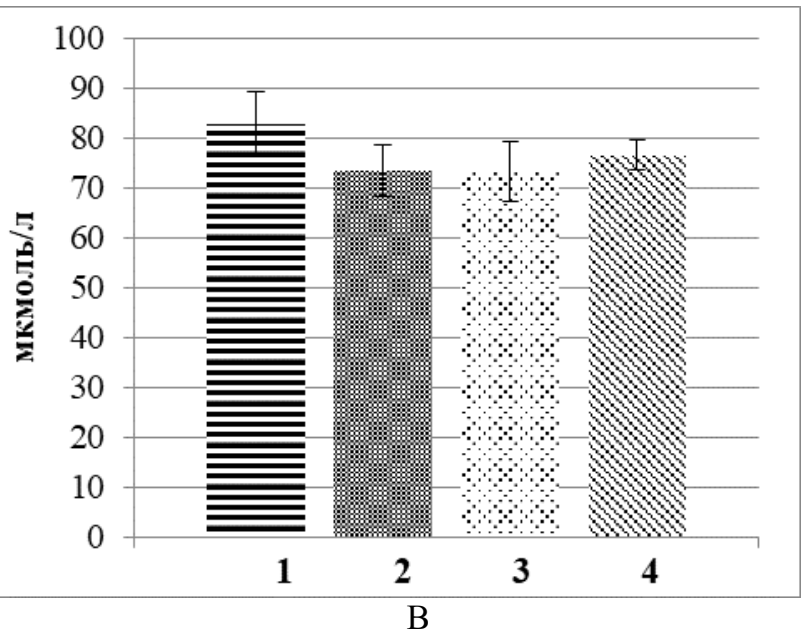

Рис. 4. Концентрація $\mathrm{H}_{2} \mathrm{~S}$ в сироватці крові (A) та гомогенатах СОШ (B) за умов норми та при AIC і BIC різної тривалості (M \pm m, $\mathrm{n}=8) .1$ - Контрольна група тварин; 2 - дія ВІС упродовж 3,5 год; 3 - вплив ВІС упродовж 5 год; 4 - дія АIC. * - P $\leq 0,05 ; * *-\mathrm{P} \leq 0,01$ порівняно з показниками тварин контрольної групи; ${ }^{\#}-\mathrm{P} \leq 0,01$ порівняно з показниками при ВІС тривалістю 3,5 год 
Дані літератури свідчать, що зменшення синтезу ендогенного $\mathrm{H}_{2} \mathrm{~S}$ в СОШ, яке спостерігали при різних моделях ульцерогенезу, спричинене змінами експресії та активності $\mathrm{H}_{2} \mathrm{~S}$-продукуючих ензимів, зумовлювало підвищення кислотності шлункового соку, розвиток оксидативного стресу із вичерпанням потенціалу глутатіонової системи антиоксидантного захисту (Guo et al., 2012; Wallace et al., 2018).

Вміст NO суттєво зростав в СОШ у відповідь на дію стресових чинників, про що свідчать зміни концентрації його стабільних кінцевих метаболітів нітрит- та нітрат-аніонів. Так, концентрація нітританіону зростає на $10 \%$ при ВIC тривалістю 5 год та на $13 \%$ при AIC, проте зазначені зміни були статистично недостовірними. Вміст $\mathrm{NO}_{2}^{-}+\mathrm{NO}_{3}^{-}$в гомогенатах СОШ був суттєво вищим за вміст самостійного $\mathrm{NO}_{2}^{-}$. Концентрація суми нітрит-аніону і нітрат-аніону зростає майже на $40 \%(\mathrm{P} \leq 0,01)$ при ВIC тривалістю 5 год та приблизно в однаковій мірі при ВIC упродовж 3 год та $\mathrm{AIC}$ (рис. 5).
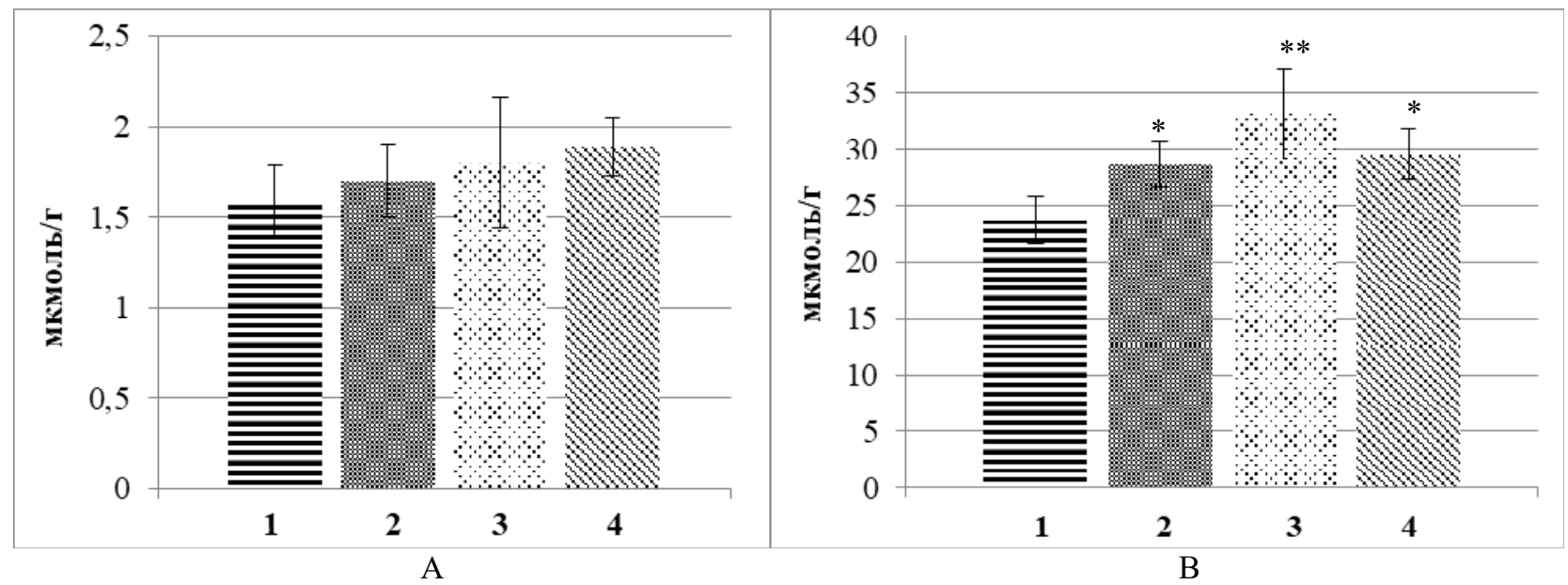

Рис. 5. Концентрація нітрит-аніону (А) та сума концентрацій нітрит-аніону і нітрат-аніону (В) в гомогенатах СОШ за умов норми та при АIC і ВIC різної тривалості $(\mathrm{M} \pm \mathrm{m}, \mathrm{n}=8)$. 1 - Контрольна група тварин; 2 - дія ВІС упродовж 3,5 год; 3 - вплив ВІС упродовж 5 год; 4 - дія АIC. * - P $\leq 0,05 ; * *-\mathrm{P} \leq 0,01$ порівняно 3 показниками тварин контрольної групи.

Результати останніх досліджень переконливо засвідчили, що надмірна кількість NO проявляє як захисні, так і цитотоксичні властивості (Bohdanova et al., 2007; Wiley, 2007; Fomenko et al., 2015). Отримані нами результати доводять цитотоксичну та прозапальну роль надлишку цього газотрансміттера за умов значного зростання його утворення при стресіндукованих ушкодженнях, оскільки гіпоксія, що має місце при зростанні концентрації адреналіну, служить передумовою для розвитку оксидативного стресу, як наслідок, NO взаємодіє із супереоксид-аніоном, перетворюється на пероксинітрит та чинить цитотоксичну дію.

Отже, направленість змін вмісту $\mathrm{H}_{2} \mathrm{~S}$ та $\mathrm{NO}$ в СОШ за умов стресу $є$ різноспрямованою: вміст стабільних метаболітів NO зростає, тимчасом як концентрація $\mathrm{H}_{2} \mathrm{~S}$ - зменшується. При цьому варто зазначити, що переважна більшість ефектів обидвох газових медіаторів є синергічною (Magierowski et al., 2015). Проведений кореліційний аналіз концентрації $\mathrm{H}_{2} \mathrm{~S}$ та суми $\mathrm{NO}_{2}{ }^{-}+\mathrm{NO}_{3}{ }^{-}$в СОШ свідчить про значний рівень їх кореляції в контрольній групі тварин (коефіцієнт кореляції Пірсона $\mathrm{r}=0,658$ ) та порівняно помірний від'ємний показник кореляції $\mathrm{r}=-0,483$, -0,509 при ВІС тривалістю в 3,5 і 5 год відповідно та слабку від'ємну кореляцію $\mathrm{r}=-0,159$ при АIC.

За умов впливу стресу в СОШ відбувається зростання активності NO-синтази (NOS). Рівень останньої в тварин контрольної групи становив 0,57 \pm 0,23 нмольНАДФН $2 /$ хв $\times Г$, при цьому рівень активності конститутивної ізоформи сNOS був достатньо високим $0,41 \pm 0,15$ нмольНАДФН $2 /$ хв $\times \Gamma$ при порівняно низькому значенні активності iNOS - 0,16 \pm 0,07 нмольНАД $\Phi \mathrm{H}_{2} /$ хв $\times$. Активність загальної NOS зростала на майже удвічі як при 3,5 год, так і при 5 год ВIC ( $\mathrm{P} \leq 0,01)$ порівняно 3 контрольними тваринами, а за умови моделювання АIC вона підвищувалась іще суттєвіше - в 3,6 разу ( $\mathrm{P} \leq 0,01)$ (табл. 1$)$.

Зростання активності загальної NOS спостерігали, головним чином, шляхом підвищення іiі індуцибельної ізоформи - iNOS (в 4 рази при 3,5 год BIC та майже у 5 разів за умов ВІС упродовж 5 год, $\mathrm{P} \leq 0,01)$. AIC зумовлював різке активування $\mathrm{iNOS}$ в понад 10 разів $(\mathrm{P} \leq 0,01)$. Водночас активність сNOS практично не змінювалась при ВIC тривалістю 5 год та AIC i лише при ВIC 3,5 год знижувалась майже удвічі. Таке зниження активності cNOS при порівняно короткотривалій дії чинників стресу, імовірно, виникає через конкуренцію ізоформ NOS за один субстрат L-аргінін, i, враховуючи різке зростання експресії гену Nos 2 (Fomenko et al., 2017), саме iNOS за рахунок збільшення концентрації білка-ферменту буде використовувати субстрат. При ВІС упродовж 5 год рівень активності cNOS практично повертався до норми (табл. 1). 
Таблищя 1

Активність ізоформ NOS та аргінази в СОШ за умов впливу BIC та AIC $(\mathrm{M} \pm \mathrm{m})$

\begin{tabular}{|c|c|c|c|}
\hline Групи тварин & $\begin{array}{c}\text { Активність iNOS } \\
(\text { нмольНАДФН } 2 / \text { хв ×Г) }\end{array}$ & $\begin{array}{c}\text { Активність сNOS } \\
\left(\text { нмольНАДФН }{ }_{2} / \mathrm{xB} \times \Gamma\right)\end{array}$ & $\begin{array}{c}\text { Активність аргінази } \\
(\text { мкмоль/хв } \times \text { г) }\end{array}$ \\
\hline $\begin{array}{c}\text { Контрольні тварини } \\
\mathrm{N}=8\end{array}$ & $0,16 \pm 0,07$ & $0,41 \pm 0,15$ & $0,34 \pm 0,04$ \\
\hline $\begin{array}{c}\text { ВІС 3,5 год } \\
\mathrm{N}=8\end{array}$ & $0,65 \pm 0,11^{* *}$ & $0,21 \pm 0,09^{*}$ & $0,22 \pm 0,02 * *$ \\
\hline $\begin{array}{l}\text { ВІС } 5 \text { год } \\
\quad \mathrm{N}=8\end{array}$ & $0,76 \pm 0,20 * *$ & $0,37 \pm 0,12$ & $0,13 \pm 0,01 * *$ \\
\hline $\begin{array}{c}\text { AIC } \\
\mathrm{N}=8\end{array}$ & $1,72 \pm 1,19 * *$ & $0,48 \pm 0,15$ & $0,25 \pm 0,03 *$ \\
\hline
\end{tabular}

$* \mathrm{P} \leq 0,05, * * \mathrm{P} \leq 0,01$ порівняно з тваринами контрольної групи

Значне зростання активності iNOS спричинювало зміни рівня активності аргінази, оскільки обидва ензима конкурують за один субстрат - L-аргінін. Зокрема, активність аргінази знижувалась на $40 \%$ при 3,5 год $\mathrm{BIC}(\mathrm{P} \leq 0,05)$ та менш виражено (на $29 \%, \mathrm{P} \leq 0,05)$ при AIC. Варто зазначити, що найсуттєвіше зниження рівня аргіназної активності (у 2,7 разу, $\mathrm{P} \leq 0,01)$ спостерігали за умов 5 год тривалості ВIC (табл. 1), що заслуговує на увагу з огляду на той факт, що найсуттєвіші зміни активності NOS мали місце при AIC.

\section{Висновки}

Отже, порівняльний аналіз біохімічних, морфологічних та гістологічних змін у СОШ при різних моделях стрес-індукованого ульцерогенезу дозволив зробити такі висновки:

1. Моделювання стресу зумовлювало формування виразкових ушкоджень в СОШ. Морфогістологічні дослідження підтвердили, що серед чинників стресу саме адреналін володіє найбільшим ульцерогенним потенціалом, оскільки при АIC моделі зміни в СОШ були найбільш вираженими.

2. Стрес-індуковані зміни супроводжувались зниженням продукції помірним зниженням концентрації $\mathrm{H}_{2} \mathrm{~S}$ в СОШ. Дефіцит синтезу $\mathrm{H}_{2} \mathrm{~S}$, що володіє антиоксидантними та протизапальними властивостями, створює передумови для формування виразкових ушкоджень СОШ.

3. Нашими дослідженнями підтверджено, що як при ВIC різної тривалості дії, так і при AIC було відмічено значне зростання продукції NO, зумовлене багаторазовим (в понад 20 разів в СОШ при моделі AIC) зростанням активності iNOS. При цьому відбувалося зниження активності аргінази в СОШ. Отже, при експериментальному стрес-індукованому ульцерогенезі метаболізм L-аргініну в СОШ однаковою мірою зміщується в бік утворення NO, що за умов посилення вільнорадикальних процесів служить передумовою активації оксидативнонітративних процесів.

\section{References}

Alhazzani, W., Alshahrani, M., Moayyedi, P., \& Jaeschke, R. (2012). Stress ulcer prophylaxis in critically ill patients:review of the evidence. Polskie Archiwum Medycyny Wewnętrznej, 122(3), 107-114. doi: 10.20452/pamw.1173.

Belostockij, N. I. (1988). Jazveobrazovanie v slizistoj obolochke zheludka krys pod vlijaniem kateholaminov. Patologicheskaja fiziologija i jeksperimental'naja medicina, 1, 24-27 (in Russian).

Bohdanova, O., Kuzmenko, L., Drobinska, O., \& Ostapchenko, L. (2007). Uchast systemy syntazy oksydu azotu $\mathrm{v}$ rozvytku ta vidnovlenni stres-indukovanykh urazhen slyzovoi obolonky shlunka. Visnyk Kyivskoho natsionalnoho universytetu imeni Tarasa Shevchenka, 12, 5-7 (in Ukrainian).

Bradley, P. P., Christensen, R. D., Rothstein, G. (1982). Cellular and extracellular myeloperoxidase in pyogenic inflammation. Blood, 60(3), 618-622. doi: 10.1182/blood.V60.3.618.618.

Brzozowski, T., Magierowska, K., Magierowski, M., Ptak-Belowska, A., Pajdo, R, Kwiecien, S., Olszanecki, R., \& Korbut, R. (2017). Recent Advances in the Gastric Mucosal Protection Against Stress-induced Gastric Lesions. Importance of Renin-angiotensin Vasoactive Metabolites, Gaseous Mediators and Appetite Peptides. Curr Pharm Des., 23(27), 3910-3922. doi: 10.2174/1381612823666170220160222.

De Palma, G., Collins, S. M., Bercik, P., \& Verdu, E. F. (2014). The Microbiota-Gut-Brain axis in gastrointestinal disorders: Stressed bugs, stressed brain or both? J. Physiol., 592(14), 2989-2997. doi: 10.1113/jphysiol.2014.273995.

Filaretova, L. Bagaeva, T., \& Morozova, O. (2012). Stress and the stomach: corticotropin-releasing factor may protect the gastric mucosa in stress through involvement of glucocorticoids. Cell Mol Neurobiol., 32(5), 829-836. doi: 10.1007/s10571-012-9800-z.

Fomenko, I. S. (2015). Rol protsesiv lipoperoksydatsii u formuvanni vyrazkovykh ushkodzhen slyzovoi obolonky tovstoi kyshky shchuriv pry riznykh modeliakh stresu. Visnyk problem biolohii ta medytsyny, 1(3), 223-226 (in Ukrainian).

Fomenko, I., Bondarchuk, T., Emelyanenko, V., Denysenko, N., Pavlo, S., \& Ilkiv, I. (2015). Changes of nitric oxide system and lipid peroxidation parameters in the digestive system of rats under conditions of acute stress, and use of nonsteroidal anti-inflammatory drugs. Current Issues in Pharmacy 
and Medical Sciences, 28(1), 37-41. doi: 10.1515/cipms-2015-0040.

Fomenko, I., Sklyarov, A., Denysenko, N., Hrycevych, N., Dranitsyna, A. (2017). Interactions between nitric oxide and hydrogen sulfide generating systems in gastric mucosa under condition of the combined action of stress and NSAIDs. J. Appl. Pharm. Sci., 7(8), 13-19. doi: 10.7324/JAPS.2017.70803.

Fomenko, I., Sklyarov, A., Bondarchuk, T., Biletska, L., Panasyuk, N., \& Wallace, J.L. (2014). Efects Of Conventional And Hydrogen Sulfide-Releasing Nonsteroidal Anti-Inflammatory Drugs In Rats With Stress-Induced And Epinephrine-Induced Gastric Damage. Stress, 17(6), 528-537. doi: $10.3109 / 10253890.2014 .967207$.

Geyer, J. W., \& Dabich, D. (1971). Rapid method for determination of arginase activity in tissue homogenates. Anal. Biochem., 39(2), 412-417. doi: 10.1016/0003-2697(71)90431-3.

Green, L. C., David, A. W. (1982). Analysis of nitrate, nitrite and (1515) nitrate in biological fluids. Anal. Biochem., 126(1), 131-138. doi: 10.1016/00032697(82)90118-x.

Guo, Sh., Gao, Q., \& Jiao, Q., Hao, W., Gao, X., \& Cao, J. M. (2012). Gastric mucosal damage in water immersion stress: Mechanism and prevention with GHRP-6. World J. Gastroenterol., 18(24), 3145-3155. doi: 10.3748/wjg.v18.i24.3145.

Huerta-Franco, M. R., Vargas-Luna, M., Tienda, P., Delgadillo-Holtfort, I., Balleza-Ordaz, M., \& FloresHernandez, C. (2013). Effects of occupational stress on the gastrointestinal tract. World J Gastrointest. Pathophysiol., 4(4), 108-118. doi: 10.4291\%2Fwjgp. v4.i4.108.

Kiselyk, I. O., Lutsyk, M. D., \& Shevchenko, L. Iu. (2001). Osoblyvosti vyznachennia nitrativ ta nitrytiv v peryferychnii krovi u khvorykh na virusni hepatyty ta pry syndromi zhovtianytsi inshoi etiolohii. Laboratorna diahnostyka, 3, 43-45 (in Ukrainian).
Kudryavtsev, K. V., Markevich, A. O., Virchenko O. V. et al. (2014). Pharmacological correction of stress-induced gastric ulceration by novel small-molecule agents with antioxidant profile. Scientific World Journal, 2014. article ID 217039. doi: 10.1155/2014/217039.

Magierowski, M., Magierowska, K., Kwiecien, S., \& Brzozowski, T. (2015). Gaseous mediators nitric oxide and hydrogen sulfide in the mechanism of gastrointestinal integrity, protection and ulcer healing. Molecules, 20(5), 9099-9123. doi: 10.3390/molecules20059099.

Mönnikes, H., Tebbe, J. J., Hildebrandt, M. et al. (2001). Role of stress in functional gastrointestinal disorders. Evidence for stress-induced alterations in gastrointestinalmotility and sensitivity. Dig Dis., 19(3), 201-211. doi: 10.1159/000050681.

Ravaieva, M. Ju. (2012). Pol' oksida azota v realizacii mikrovaskuljarnyh jeffektov nizkointensivnogo millimetrovogo izluchenija. Uchenye zapiski Tavricheskogo nacional'nogo universiteta im. V. I. Vernadskogo Serija "Biologija, himija", 64(3), 165-170 (in Russian).

Takagi, K. Y., Kayuya, Y., \& Watanabe, K. (1964). Studies on drugs for peptic ulcer. A reliable method for producing stress ulcers in rats. Chem Pharm Bull., 12, 465-472. doi: 10.1248/cpb.12.465.

Wallace, J. L., Motta, J. P., \& Buret, A. G. (2018). Hydrogen sulfide: an agent of stability at the microbiome-mucosa interface. Am J Physiol Gastrointest Liver Physiol., 314(2), G143-G149. doi: 10.1152/ajpgi.00249.2017.

Wiley, J. W. (2007). The many faces of nitric oxide: cytotoxic, cytoprotective or both. Neurogastroenterol Motil., 19(7), 541 - 544.

Wilinski, B., Wilinski, J., Somogyi, E., Piotrowska, J., \& Góralska, M. (2011). Digoxin increases hydrogen sulfide concentration in brain, heart and kidney tissues in mice. Pharmacol. Rep., 63(5), 1243-1247. doi: 10.1016/s1734-1140(11)70645-4. 